\title{
LA ONOMÁSTICA EN RAFAEL LAPESA
}

Manuel Ariza

Si mi memoria no me falla, son sólo cuatro los trabajos que don Rafael dedicó a la onomástica. Se puede decir, en consecuencia, que es el aspecto que menos le interesó de la Historia de la Lengua Española. Ello no quita para que haya sido el primer profesor que impartiese clase en España de una asignatura que se mal llamaba Toponimia y onomástica, asignatura que yo cursé como alumno de doctorado y que fue la base para mis primeros conocimientos en esa especialidad.

Bien es verdad que -como no podía ser menos- la onomástica ocupa un lugar importante en su Historia de la lengua española, por lo que no podemos por menos que referirnos también a su manual al hablar de este tema.

Pero, para seguir el esquema aconsejado por los organizadores, conviene empezar viendo cuál era el panorama en los estudios de onomástica.

Como en tantas otras cosas, uno de los pioneros de la investigación científica en onomástica fue don Ramón Menéndez Pida], cuyos Orígenes del español están llenos de referencias onomásticas, sobre todo toponímicas, pues no en vano son los topónimos los nombres más difíciles de "latinizar" o, incluso, de conocer su étimo latino, por lo que los notarios medievales con relativa frecuencia los escriben como se pronunciaban, dándonos, así, preciosos testimonios del romance temprano. Es posible pensar que estas formas toponímicas romances obedecieran -al menos en algunos casos- no ya a desconocimiento etimológico sino a una voluntad de escribirlas como se decían, habida cuenta de la importancia que tenían en la documentación medieval para fijar los términos de una donación, los límites de una compra o venta o el espacio que comprendía un dominio, de ahí la frecuencia de expresiones como "que dicen", "que llaman" y similares.

Pero no fueron solo los Orígenes en donde don Ramón señaló el camino a seguir; ya en 1918 había publicado su primer estudio con base toponímica, a los que siguieron otros recogidos en el conocido libro Toponimia prerrománica hispánica. La onomástica de don Ramón se orientó casi siempre hacia los problemas del sustrato prerromano y a la llamada colonización suritálica de la Península Ibérica ${ }^{2}$.

Es de notar que la mayoría de los trabajos toponímicos de don Ramón discurren entre las décadas de los años 40 y 50, años de suma importancia para la onomástica peninsular.

\footnotetext{
En el tomo V de la RFE. Ciertamente era más un estudio de fonética histórica que de onomástica.

${ }^{2}$ Salvo su estudio "Onomástica inspirada en el culto mariano", que no deja de ser un esbozo.
} 
Será, como digo, en estas décadas cuando aparezcan las más importantes aportaciones de Aebischer, Alvar, Asín, Badía, Caro Baroja, Dolç, Michelena, Seguy, etc., y muchos de los trabajos de Corominas, Oliver Asín, Piel y Tovar. Décadas que tendrán su culminación en 1959 con la publicación de la Enciclopedia Lingüística Hispánica.

Ciertamente en años anteriores algunos investigadores habían realizado ya valiosísimas aportaciones a la onomástica peninsular, como son Griera, Sachs o Schuchardt, por citar solo algunos nombres, pero la "explosión onomástica" acaecerá en la década de los cincuenta y ya no se interrumpirá.

Esta progresión en los conocimientos de la onomástica, que muchas veces iban unidos a otros de mayor interés general para la historia de la lengua, se irían viendo reflejados en las distintas ediciones de la Historia de la Lengua de don Rafael ${ }^{3}$. En la novena edición -1981se añadió un índice de los topónimos y antropónimos estudiados en el libro ${ }^{4}$ que nos habla de la importancia de este aspecto en el libro de don Rafael. A la toponimia dedica los apartados 1.1, 1.7, 1.8, 3, 4, 5 y 6 del primer capítulo, la onomástica ocupa el apartado 22.1 del segundo capítulo -uno de los dedicados al posible sustrato suritálico; fundamentales son las referencias onomásticas del apartado dedicado a los visigodos -capítulo IV- y las toponímicas del 34 -capítulo V- de origen árabe. A partir de entonces las referencias onomásticas son esporádicas.

No es el momento de exponer con particularidad las teorías y ejemplos de don Rafael, entre otros motivos porque están recogidas en uno de sus estudios: La toponimia como herencia histórica y lingüística, publicado en el libro titulado Coloquio de toponimia ${ }^{5}$. En él don Rafael nos expone lo que en su opinión significa la toponimia para un filólogo:

"La toponimia interesa al lingüista como la paleontología al biólogo; o, mejor, como la arqueología o la documentación de otras épocas interesan al historiador"

La toponimia tiene solo "un valor auxiliar". Después hace un repaso histórico de los distintos elementos que componen la toponimia española: prerromano, latino, visigodo, árabe, los topónimos de la reconquista. Después pasa a analizar algunos aspectos particulares de la toponimia: los problemas etimológicos, la conservación en la toponimia de palabras latinas desaparecidas, cambios fonéticos conservados en topónimos, la etimología popular, los eufemismos.

Como vemos es un precioso resumen de la cuestión toponímica realizado con criterios de divulgación, de ahí que no contenga notas ni bibliografía. Precisamente porque es

\footnotetext{
${ }^{3}$ Véase su esplendoroso artículo "Historia de una 'Historia de la lengua", en Actas del I Congreso Internacional de $H^{z}$ de la Lengua Española, Madrid, 1988, I, pp. 1771-1785.

${ }^{4}$ Índice realizado por Eduardo Tejero

${ }^{5}$ Madrid, 1972, pp. 9-23

${ }^{6}$ P. 9
} 
esencialmente un resumen -basado en los trabajos de la E.L.H.-, voy a comparar lo que aquí se dice con lo expuesto años más tarde en la Historia de la Lengua.

\section{Lenguas prerromanas}

Dejando a un lado el hecho de que en la Historia aparecen más ejemplos, algunas diferencias significativas hay entre ambos escritos, así, en lo referente a la toponimia "vasca", el artículo es, curiosamente, más cauto en las afirmaciones, pues en él se habla de "Una capa lingüística similar al vasco", mientras que en la Historia no se matiza tanto. En cuanto a la toponimia indoeuropea las diferencias son mínimas.. Sí merece citarse lo que se dice sobre el sufijo -én, -ena: en La toponimia se expone que "Menéndez Pidal (lo) ha señalado como resto de posible sustrato mediterráneo", mientras que en la Historia se dice que "en el sufijo -én, -ena de los topónimos peninsulares de base antroponímica parecen haber confluido factores de diverso origen; uno de ellos ha debido ser vasco" (p. 35)

\section{Toponimia latina}

En La toponimia recoge don Rafael algunos ejemplos de topónimos de origen latino ${ }^{7}$, punto este que no existe en la Historia, salvo en lo referente a la existencia de colonizadores suritálicos.

\section{Toponimia germánica}

En ambos escritos se citan casi los mismos ejemplos; la única diferencia notable es que en La toponimia se dice que "la victoria de Leovigildo sobre los cántabros y váscones se conmemoró con el nombre de Victoria, la actual Vitoria", referencia que ha desaparecido de la Historia; no es de extrañar, en la separata que yo poseo aparece subrayada a lápiz la frase citada y al margen, con letra de don Rafael, "Ojo".

Antes de pasar a la toponimia árabe don Rafael incluye un apartado de hagiotoponimia, variando en esto el orden que tal capítulo tiene en la E.L.H.

\section{Toponimia árabe}

Nada tiene que ver lo que se dice en la toponimia con lo que aparece en la Historia, por más que algunos ejemplos coincidan.

\section{Toponimia de reconquista}

Hace aquí don Rafael un buen resumen de lo dicho por F. Marsá, aunque ampliando algunos aspectos que no están en el estudio de Marsá. En este sentido es interesante observar que algunas de sus afirmaciones son matizadas a mano en la separata que tengo: la identificación de Torreperogil con Pedro el Cruel es apostillada con "comprobar", y la de Villarreal de los Infantes con los hijos de don Fernando de Antequera con la de "ojo".

\footnotetext{
${ }^{7}$ Entre ellos Teberga en Asturias, topónimo sobre el que ya hace varios años, J.L. García Arias mostró que no tenía nada que ver con Tiberio sino que encerraba la raíz céltica briga
} 
Finalmente la segunda parte de La toponimia no se encuentra reflejada en la Historia ${ }^{8}$.

El más antiguo artículo de onomástica de don Rafael es el titulado Aldonza- Dulce Dulcinea, publicado en $1947^{9}$; en él nos hace un impresionante recorrido histórico sobre el origen de la confluencia del nombre germánico Aldonza con el de Dulce, para explicar por qué en el siglo XVII se creía que el primero era deformación del segundo, como afirmaba Covarrubias, y que explica el ennoblecimiento onomástico de Aldonza Lorenzo, nombre, por cierto, que había sido propio de nobles en la Edad Media, pero que ya en el siglo XVI era propio de plebeyos, como bien señalaba el citado Covarrubias.

No es hasta 1973 cuando don Rafael vuelve a tratar un aspecto onomástico con su trabajo Sobre transliteración de nombres propios extranjeros ${ }^{10}$. En realidad es un extenso informe sobre la reunión habida en Londres para estudiar la transliteración de los nombres propios en caracteres latinos para aquellas lenguas que no tenían ningún código de escritura o que usaban oto distinto, como el ruso o el árabe. Don Rafael expone las consecuencias que tiene la recomendación realizada para el árabe y el ruso y realiza una serie de propuestas para que sean estudiadas por las Academias de Lengua Española.

Finalmente, en 1988 publicó su trabajo Sobre el origen de Sancho ${ }^{11}$, en el que continúa con la investigación llevada a cabo por el profesor S. Mariner sobre el origen del citado antropónimo. Considera don Rafael que la formas como Sanz provienen de un genitivo latino SANCTII, SANCII o SANTII, mientras que para las formas actuales con /č/ postula un diminutivo SANCTULU, aunque podría también "pensar en una alternancia /s/-/č/ como las de çimçe-chinche". Deja sin explicar, de todas formas, la /i/ de Sainz.

Finalmente no puedo dejar de citar el siguiente texto:

"Este patronímico ${ }^{12}$ es muy frecuente en los documentos navarros desde 1042 , y su $c$ o $z$, perpetuados en la $/ \theta /$ de nuestro actual $\operatorname{San} z$, prueban que la articulación antigua era la dental africada /ŝ/ o, más probablemente en posición implosiva, la espirante $/ \theta /$ ya."

Lo destaco porque, que yo sepa, es la primera vez que don Rafael señala una cronología tan temprana para el proceso a fricativa de la dentoalveolar africada en situación implosiva.

Como decíamos al principio, no es mucho lo que don Rafael ha aportado al campo de la onomástica $^{13}$, que no ha sido nunca uno de sus empeños más queridos, pero aun así, en sus trabajos es el don Rafael de siempre: preciso, claro, rotundo, magistral.

\footnotetext{
${ }^{8}$ Salvo las referencias a nombres prerromanos.

${ }^{9}$ Recogido más tarde en el volumen De la Edad Media a nuestros días

${ }^{10}$ BRAE, LIII, 1973, pp. 279-287.

${ }^{11}$ Homenagem a J. M. Piel, Tübingen, 1988, pp. 79-83

${ }^{12}$ Se refiere a Sanz

${ }^{13}$ Los artículos "La toponimia...", "Aldonza..." y "Sobre el origen..." fueron recogidos en el libro Léxico e Historia. I. Palabras, Msdrid, 1992, Ed. Istmo.
} 